\title{
KEPMENPERINDAG RI NO. 651/MPP/KEP/10/2004 DALAM PRAKTEK PENGOLAHAN DEPOT AIR MINUM ISI ULANG DI KECAMATAN BALONG DALAM PERSPEKTIF MASLAHAH
}

\author{
Achmad Baihaqi \\ Fakultas Syari' ah IAIN Ponorogo \\ Abayhaque.qie@gmail.com
}

Ervina Nikmaturrohmawati

IAIN PONOROGO

viena.1996@gmail.com

\begin{abstract}
Through the maslahah approach, various forms of transactions including buying and selling and sharia financial innovations not only have a legal basis as a basis for their application, but can also be examined more deeply about their benefit. With the development of human civilization, the buying and selling system has evolved into a modern form. For example, the activity of buying and selling drinking water refills which leads to a water treatment process so that it can be drunk immediately. Based on the existing provisions, there are still many depot drinking water refill business actors that have not complied with the provisions of the Indonesian Ministry of Industry and Trade No. 651 / MPP / KEP / 10/2004. They sell and market branded gallons of refill water. In addition, the drinking water depot also provides stock or stores large quantities of raw water in empty gallon containers. The approach used in this paper is a qualitative approach. Meanwhile, data collection techniques are using interviews and documentation. Data analysis using interactive methods. In this paper, it can be concluded that the use of branded gallons in buying and selling refill water in Balong District deviates from the KEPMENPERINDAG RI Regulation No.651 / KEP / MPP / 10 / 2004. From the maslahah approach, this is not appropriate. Filling raw water to gallons in buying and selling drinking water refill in Balong District is not in accordance with KEPMENPERINDAG RI No.651 / KEP / MPP / 10/2004. Analyzed with the maslahah theory this is not in accordance with maslahah aldaruriyah hifz al-nafs in order to nurture the soul, because to make it happen, Islam requires its followers to eat and drink something that can be healthy and can provide resistance to the soul.
\end{abstract}


Kepmenperindag RI No. 651/mpp/kep/10/2004 Dalam praktek pengolahan depot air minum...

Keywords: Maslahah, KEPMENPERINDAG RI No. 651/MPP/KEP/ 10/2004, Water Refill, Brand.

ABSTRAK: Lewat pendekatan maslahah, bermacam wujud transaksi bisnis serta macam-macam pembiayaan syariah tidak cuma mempunyai dasar aturan hukum bagaikan dasar untuk mempraktekkanya, namun juga bisa dipelajari dan diteliti secara lebih mendetail tentang kemaslahatannya. Seiring dengan terus berkembangnya peradaban manusia, model-model bisnis terus berinovasi ke wujud yang bertabiat modern, misalnya aktivitas perdagangan air minum isi ulang yang menuju kepada proses pengolahan air yang higienis sehingga langsung bisa diminum. Bersumber pada syarat yang telah disebutkan dalam aturan pemerintah, banyak pelakon bisnis depot air minum higienis yang diisi ulang belum cocok dan sesuai seperti yang di tulis dalam KEPMENPERINDAG RI Nomor. 651/ MPP/ KEP/ 10/ 2004. Distributor memasarkan isi air higienis yang di isi ulang dengan galon yang berlabel. Tidak hanya itu depot air minum higienis tersebut menyediakan pula persediaan ataupun melaksanakan stok air baku yang masih dalam olahan ke dalam galon kosong dalam jumlah yang tak terhitung. Dalam Pendekatan yang digunakan maka penulis menyusunnya ke dalam pendekatan kualitatif. Sedangkan metode pengumpulan informasi merupakan memakai wawancara serta dokumentasi. Analisis informasi memakai tata cara interaktif. Dalam penyusunan ini bisa disimpulkan kalau pemakaian galon berlabel dalam bisnis air isi ulang higienis di Kecamatan Balong tidak sesuai dari peraturan Keputusan Menteri Perindustrian Dan Perdagangan RI Nomor. 651/ KEP/ MPP/ 10/ 2004. Ditinjau dari segi metode maslahah, perihal tersebut tidaklah cocok. Pengisian air higienis ke wadah galon dalam bisnis air minum isi ulang di Kecamatan Balong tidak cocok dengan KEPMENPERINDAG RI Nomor. 651/ KEP/ MPP/ 10/ 2004. Penulis menganalisis dengan teori maslahah perihal tersebut tidak cocok dengan maslahah al-daruriyah serta hifz al-nafs dalam rangka memelihara jiwa, karena buat mempraktekannya, Islam mengharuskan umatnya untuk makan minum dari suatu yang bisa menyehatkan serta bias memberikan ketahanan terhadap jiwa.

\section{Kata Kunci: Maslahah, KEPMENPERINDAG RI No. 651/MPP/KEP/10/2004, Air Isi Ulang, Merek.}




\section{PENDAHULUAN}

Pada prinsipnya tuhan yang maha esa menciptakan serta memberlakukan aturan yang tujuannya dapat menciptakan kemanfaatan untuk keselamatan mahluk hidup. Dengan harapan keuntungan itu berupa kebahagiaan ataupun penolakan kerugian bagi kehidupan manusia. ${ }^{1}$ Maslahah harus diteguhkan dengan tujuan Shyara, yaitu dengan pernyataan hukum tertentu yang membenarkan atau membatalkan semua perbuatan manusia demi menjaga jiwa, akal, harta dan warisan (keturunan). ${ }^{2}$

Imam al-Ghazali berpendapat bahwa harus ada kepentingan yang tidak sesuai dengan tujuan Shara. "Meski ini bertentangan dengan tujuan manusia, karena kepentingan manusia tidak selalu berdasarkan kehendak Shara."

Jadi, keuntungan maslahah adalah tidak membatalkan bila tidak ada bukti, tetapi ada peristiwa dalam syariah yang tidak mengandung ketentuan apapun, dan tidak ada inisiasi illat dalam syariah. Definisi kejelasan hokum, mengungkapkan sesuatu yang sejalan dengan hukum. Artinya, mengambil keputusan berdasarkan uraian tentang konservasi atau manfaat dari kerusakan, maka peristiwa tersebut disebut maslahah. Tujuan dan Manfaat maslahah. ${ }^{3}$

Melalui pendekatan Maslahah-Mursalah Berbagai bentuk transaksi dan inovasi keuangan Islam dapat dicermati manfaatnya, dan juga dapat memiliki landasan hukum sebagai landasan pelaksanaannya. ${ }^{4}$

Dalam firmannya Allah SWT mengatakan :

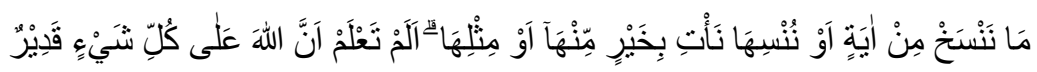

${ }^{1}$ Asmawi, Studi Hukum Islam (Yogyakarta: Sukses Offset, 2012), 107.

2 Mardani, Fiqhi Ekonomi Syariah; Fiqh Muamalah (Jakarta: Kencana Prenamidia Group, 2012), 10.

${ }^{3}$ Rahmad Syafi'i, Ilmu Ushul Fiqh (Bandung: Pustaka Setia,1999), 117.

${ }^{4}$ Ahmad Qorib, Penerapan Maslahah Mursalah Dalam Ekonomi Islam," Analytica Islamica, 1 (2016), 56. 
Artinya: “Apapun ungkapan yang kami nasakhan, atau apa yang membuat (orang) lupa, kami membawakan Anda sesuatu yang serupa. Apakah kamu tidak tahu bahwa Allah mengatur segalanya? “(Surat al-Bakara: 106). ${ }^{5}$

Berdasarkan ayat ini, para ulama menetapkan aturan Ushul Fiqh yang berupa perkataan, jika seseorang benar-benar memahami Syariah Islam, dia akan tahu apa prinsipnya. Secara umum (almaslahah al-mursalah) menempati tempat penting dalam syariah Dengan pengecualian hukum ibadah, semua hukum Alquran dan hadits harus didasarkan pada kepentingan umum masyarakat bahwa Allah SWT berkeinginan. Dengan demikian, pemanfaatan untuk kepentingan umum tersebut merupakan salah satu sumber ilmu hukum Islam dan telah disepakati sebagai salah satu alternatif pemecahan masalah perkembangan hukum Islam. ${ }^{6}$

Yang dimaksud dengan ketentuan hokum adalah persyaratan yang menyenangkan, pilar dan segala sesuatu lainnya yang berkaitan dengan bisnis. Adapun benda itu sendiri meliputi sesuatu yang bernilai yang dapat diwariskan seperti harta benda dan uang, sedangkan sifat dari benda tersebut harus dapat dinilai, khususnya harta benda yang memiliki nilai serta dapat dibenarkan penggunaannya dengan cara syara '. ${ }^{7}$

Air merupakan kebutuhan pokok yang mengandung herbal serta dibutuhkan dan banyak dicari makhluk hidup, khususnya manusia. air adalah benda yang penting bagi mahluk hidup untuk mengatur suhu tubuh, melancarkan pencernaan untuk proses kimiawi tubuh, menghilangkan kotoran dan penyakit yang ada dalam tubuh, dan mendistribusikan nutrisi ke seluruh jaringan sel-sel badan mahluk hidup. Sekitar $70 \%$ badan manusia terdiri dari air. Sehingga kebutuhan akan air yang mudah dan higienis menjadi penting seiring bertambahnya pertumbuhan penduduk.

${ }^{5}$ Departemen Agama RI, Al-Quran Al-Kariim, (Semarang: Karya Toha Putra, 2002), 170.

${ }^{6}$ Amin Farih, Kemaslahatan \& Pembaharuan Hukum Islam (Semarang:

Walisongo Press, 2008), 31-33.

${ }^{7}$ Hendi Suhendi, Fiqih Muamalah (Jakarta: PT Raja Grafindo Persada, 2002), 68-69. 
Keputusan Menteri Perindustrian dan Perdagangan Republik Indonesia No. 651 / MPP / KEP / 10 / 2004. Mengenai Persyaratan mutlak Depot dan Perdagangan Air. Pasal 7 ayat (3) menyatakan bahwa "Depo Air Minum hanya diperbolehkan menyediakan wadah tidak bermerek atau wadah yang tidak dapat disangkal" Ayat (1) telah mengatur bahwa "Depot Air Minum hanya diperbolehkan untuk sekaligus mempromosikan produknya kepada pembeli di area depot dengan cara mengisinya. Galon dibawa oleh pelanggan atau disediakan depot ".Ayat (2), yaitu "Depot Air Minum dilarang menyimpan barang dagangan air minum dalam wadah yang disiapkan untuk dijual".

\section{PEMBAHASAN}

Jual beli adalah salah satu hal yang harus dilakukan di bidang muamalah, Prinsip sederhana muamalah yang telah dipasang dengan menggunakan aturan hokum Islam dalam disiplin perdagangan adalah tolak ukur untuk melakukan sesuatu yang didasarkan sepenuhnya pada kejujuran, amanah dan ketulusan. Dengan perkembangan peradaban manusia, sistem belanja dan promosi semakin berkembang dari bentuk yang sangat mudah menjadi bentuk seperti saat ini, Misalnya bisnis jual beli air isi ulang yang merubah air yang tidak higienis berujung pada prosedur terapi air yang melalui tahapan pemurnian dan pembersihan isi semua mikroorganisme patogen tanpa harus dimasak agar bisa langsung dikonsumsi. Bisnis depot penampung air higienis yang di isi ulang mulai meningkat dan menjamur disetiap daerah perkotaan metropolitan bahkan di daerah yang jauh dari kota. Salah satu upaya pemenuhan kebutuhan akan air minum higienis dilakukan dengan bantuan para pengusaha depot air minum di kecamatan Balong, Kabupaten Ponorogo. Dalam mengelola usaha bisnisnya, banyak pengusaha depot pengisian air minum melayani pula isi air minum dalam kemasan gallon. Beberapa teknik pemasarannya menggunakan cara anatar jemput (sistem delivery order), khususnya melalui pengiriman order ke berbagai tempat.

Keputusan Menteri Perindustrian dan Perdagangan Republik Indonesia No. 651 / MPP / KEP / 10/2004 tentang Persyaratan 

minum...

Teknis Depot dan Perdagangan Air. Pasal 7 ayat (3) menyatakan bahwa "Depot Air Minum hanya diperbolehkan untuk mensuplai galon tidak bermerek atau galon polos tanpa merk". Ayat (1) telah menetapkan bahwa "Depot Air Minum hanya diperbolehkan untuk menjual langsung hasil produksinya kepada konsumen di tempat depot dengan cara mengisi wadah yang dibawa oleh pembeli atau disediakan depot ". Ayat (2), khususnya" Depot Air Minum dilarang menyimpan barang dagangan dalam wadah galon yang disiapkan untuk dijual ".8

Berdasarkan fakta yang ada dilapangan, banyak pelaku bisnis niaga air higienis yang mengisi depot konsumsi air di Kecamatan Balong, Kabupaten Ponorogo yang hingga sekarang masih tidak sesuai dengan ketentuan. KEPMENPERINDAG RI No. 651 / MPP / KEP / 10/2004 sebagaimana yang dikerjakan salah satu pengusaha depot air di Kecamatan Balong, khususnya Depo Delta, Dalam praktek bisnis air minum higienis Delta Pengusaha depot menjual dan memasarkan air kemasan dengan wadah atau galon bermerek. Selain itu, depot air minum juga memberikan persediaan atau menyimpan porsi besar dari wadah galon kosong, Hal ini dilakukan untuk membuat pesanan pengiriman ke rumah pelanggan dan lalu gantilah dengan gallon kosong dari pembeli. Persediaan stok juga yang seharusnya langsung dibeli dalam prakteknya dititipkan ke toko, kios atau warung. ${ }^{9}$

\section{MASLAHAH}

\section{Memahami Maslahah}

Maslahah adalah bentuk masdar dari asal kata shalahah dan saluha yang secara etimologis berarti: manfaat, manfaat dan layak. ${ }^{10}$ Secara etimologis, kata "المصلحة", jamak "المصالح" skill sesuatu yang baik, yang berguna dan berlawanan dengan arti kata yang mengerikan atau merusak dan dalam bahasa Arab juga sering disebut sebagai "الخيرو الصو اب" yang cocok dan otentik. Maslahah sesekali dikenal juga

${ }^{8}$ Bagian 7 Keputusan Menteri Perindustrian dan Perdagangan Republik Indonesia Nomor 651 /MPP /KEP /10 /2004 Tentang Persyartan Teknis Depot Air Minum Isi Ulang dan Perdagangan.

${ }^{9}$ Katimun, Hasil Wawancara, Hari Kamis, Tanggal 24 Oktober 2019.

${ }^{10}$ Asmawi, Perbandingan Ushul (Jakarta: Amzah,2011),128 

minum...

dengan (الاستصلاح) yang artinya menemukan sesuatu yang baik. ${ }^{11}$ Dari berbagai pengertian yang disebutkan boleh ditarik suatu pemahaman bahwa semua hal yang mengandung kebaikan di dalamnya, baik untuk mendapatkan manfaat, kebaikan atau menjauhkan kesusahan atau tidak, maka semua ini disebut maslahah. ${ }^{12}$

Menurut Jalaluddin Abdurrahman secara tegas menyatakan bahwa maslahah dalam nuansa ekstra adat dan apa yang diinginkan adalah semua yang benar-benar memberi manfaat bagi mahluk hidup khususnya manusia, baik yang berguna untuk menggapai kebaikan maupun kesenangan serta yang membuang kesulitan atau kesusahan. Dengan kata lain, dapat dipahami bahwa hakikat maslahah itu adalah penciptaan kebaikan dan kesenangan dalam gaya hidup manusia dan menghindari segala sesuatu yang merusaknya. Akan tetapi, maslahah itu terkait dengan tatanan nilai-nilai yang benar dan tepat yang jelas dibutuhkan dengan jalan maslahah.

Imam Al-Ghazali mengemukakan bahwa pada prinsipnya maslahah adalah memanfaatkan dan menolak kemudaratan untuk menjaga tujuan hukum syara ', padahal menuju impian manusia karena pada kenyataannya apa yang diperolehan manusia tidak lagi seperti biasanya. terutama berdasarkan pada keinginan nafsu duniawi. Sebab itulah, yang dijadikan pegangan dasar dalam mengidentifikasi maslahah adalah kemauan dan bermuara pada syara, tidak lagi kemauan dan tujuan manusia. Imam Al-Ghazali menjelaskan maslahah adalah menjaga 5 maqasid al-shari'ah (tujuan penting syariat), yaitu melindungi agama, melindungi akal, mempertahankan hidup, melindungi keturunan dan melindungi harta benda.

Adapun apa yang dimaksud dengan bantuan maslahah yang dikutip melalui Imam Syatibi yang telah mendefinisikan maslahah dengan tiga ukuran berikut :

1. Tidak bertentangan maqasid shari'ah (tujuan dan hikmah rahasia syariat kepada seluruh manusia) daruriyah (menjaga agama, jiwa, akal, keturunan dan harta)

${ }^{11}$ Romli SA, Studi Perbandingan Ushul Fiqh (Yogyakarta: Pustaka Pelajar, 2004), 217-218.

12 Abbas Arfan, Geneologi Pluralitas Madzab dalam Hukum Islam (Malang: UIN Malang Pers, 2008), 82. 

minum...

2. Masuk di akal, artinya bisa lumrah dengan bantuan intelektual

3. tiga Menghasilkan raf'ul al-haraj (meningkatkan kesulitan). ${ }^{13}$

Dalam bukunya Jasser Auda mengatakan, maqasid itu ialah sesuatu yang ingin didapat dengan jalan petunjuk agama atas dasar memaksimalkan kemudahan (maslahah) dan meminimalkan kerusakan dan kesulitan (mafsadah). Maqasid yaitu bentuk jamak dari maqsad yang artinya: tujuan, rahasia, niat, prinsip. Dalam bahasa sederhana, Jasser Auda mengilustrasikan bahwa jawaban atas setiap pertanyaan mengapa (Why) ialah maqasid, kenapa orang (manusia) diciptakan? Kenapa manusia dinasehati untuk shalat, berpuasa, dan berzakat? Mengapa kebijakan seperti ini dan ada kumpulan pertanyaan maqasid, Jadi dalam maqasid, makna, tujuan, dan rahasia di balik sesuatu dalam konteks non sekuler adalah teks wahyu yang merupakan tujuan maqasid. Banyak kritik terhadap maqasid klasik, diantaranya:

Pertama, peningkatan sasaran maqasid. Dalam maqasid klasik tidak terdapat klasifikasi yang bervariasi. Akibatnya sering terjadi tumpang tindih antar maqasid saat ini. Untuk menghindari hal tersebut, klasifikasi mutakhir membagi maqasid menjadi tiga macam tingkatan : umum ('Aamah), khusus, (Khossoh) dan parsial maqasid 'Ammah (maqasid umum) terletak di semua komponen agama, bersifat Universal Seperti keadilan, kebebasan, kenyamanan, persamaan. Maqasid yang berbeda (al-maqasid al-khassah) ada di bagian tertentu dari hukum Islam, karakternya unik. Misalnya proteksi dari monopoli dalam undang-undang moneter, pemenuhan kebutuhan bayi dalam undang-undang rumah tangga. Maqasid parsial (al-maqasid al-juziyah) terletak dalam teks atau hukum tertentu. Seperti adanya 'adam al-haraj (menghilangkan kesulitan) adalah niat di belakang untuk membiarkan pria atau wanita yang sakit tidak lagi berpuasa.

Kedua, peningkatan jangkauan yang diselimuti melalui maqasid. Maqasid klasik lebih mengarah mikro, hanya dalam domain

${ }^{13}$ Muhammad Anharullah, Beralkohol Tapi Halal Menjawab Keraguan Tentang Alkohol Dalam Makanan, Minuman dan Kosmetik, (Solo: Pustaka Aarafah , 2011), 55. 

minum...

individu. Maqasid kontemporer menarik maqasid ke wilayah makro, khususnya masyarakat, bangsa, bahkan umat manusia.

Ketiga, perbaikan induksi dari sumbernya. Maqasid klasik diturunkan dari literatur fiqh, sehingga maqasid masa kini sekaligus diekstrak dari teks yang datang dari Alloh.

Dari Ketiga faktor ini Jasser Auda menghimbau perlunya digeser paradigma maqasid, jika tetap melanjutkan paradigma sejarah, hal tersebut tidak akan mampu menjawab tantangan keadaan. Paradigma maqasid klasik adalah keselamatan (perlindungan) dan renovasi (proteksi, pelestarian), yang sesuai area, jangkauan dan pasokan induksi masih sempit. Oleh karena itu ingin digeser ke paradigma baru yang menekankan pada perbaikan (pembangunan, pembangunan) dan hak asasi manusia (HAM). Menjaga agama (hifz al-din), tidak lagi dimaknai agar tidak murtad, tetapi sebagai alternatif menghormati kebebasan beragama atau memiliki keyakinan. Memelihara keturunan (hifz al-nasl) diakselerasi untuk lebih terlibat dalam kelembagaan rumah tangga. Mempertahankan tujuan (hifz al'aql) berarti menciptakan alur pikir dan penelitian sains, menemukan pemahaman dan menekankan sikap yang senantiasa menjaga kehormatan (hifz al-afs wa al-'irdl) serupa dengan membela martabat manusia; membela hak asasi manusia. Menjaga harta benda (hifz almal), memprioritaskan kepedulian sosial, pembangunan, pembangunan keuangan, kesejahteraan sosial. ${ }^{14}$

\section{Tabel Pergeseran Paradigma Teori Maqasid Klasik menuju} Kontemporer. ${ }^{15}$

\begin{tabular}{|l|l|l|}
\hline NO & Teori Maqosid Klasik & Teori Maqosid Kontemporer \\
\hline 1 & Hifz al-nasl & $\begin{array}{l}\text { Teori yang orientasinya pada } \\
\text { proteksi keluarga; dan Kepedulian } \\
\text { yang lebih besar untuk institusi } \\
\text { rumah tangga }\end{array}$ \\
\hline
\end{tabular}

14 Hamka Husein Hasibuan, “Jasser Auda, Bapak Maqasid Syariah Kotemporer ," dalam https://islami.co/jasser-auda-bapak-maqasid-syariahkontemporer/ (diakses pada 29 Maret 2020, jam 19.30).

${ }^{15}$ Muhammad Iqbal Fasa, "Reformasi Pemahaman Teori Maqașid Syariah Analisis Pendekatan Sistem Jasser Auda,” Jurnal Studia Islamika, 13 (2016), 232. 
Kepmenperindag RI No. 651/mpp/kep/10/2004 Dalam praktek pengolahan depot air minum...

\begin{tabular}{|l|l|l|}
\hline 2 & Hifz al-'aql & $\begin{array}{l}\text { Menggandakan pola pikir dan } \\
\text { penelitian ilmiah; mengutamakan } \\
\text { ekspedisi untuk mencari ilmu } \\
\text { menekan pola pikir yang } \\
\text { mengedepankan kriminalitas massa } \\
\text { menghindari upaya meremehkan } \\
\text { karya cipta }\end{array}$ \\
\hline 3 & Hifz al-nafs wa al-'irdl & $\begin{array}{l}\text { Menjaga dan melindungi hak asasi } \\
\text { manusia. menjaga harkat dan } \\
\text { martabat manusia }\end{array}$ \\
\hline 4 & Hifz al-din & $\begin{array}{l}\text { Melindungi, menjaga dan } \\
\text { mengagumi kebebasan beragama } \\
\text { dan berkeyakinan .. }\end{array}$ \\
\hline 5 & Hifz al-mal & $\begin{array}{l}\text { Kepedulian social diutamakan; } \\
\text { mengawasi perkembangan dan } \\
\text { peningkatan ekonomi, mendorong } \\
\text { kesejahteraan masyarakat. }\end{array}$ \\
\hline
\end{tabular}

\section{Klasifikasi Maslahah}

a. Dari Tingkatan Maslahah

Apa yang dimaksud melalui jenis-jenis maslahah dalam frase tingkatannya terkait dengan masa lalu yang merupakan kebutuhan hidup manusia. Keinginan akan al-daruriyah adalah perolehan hakiki dalam mewujudkan dan mempertahankan keberadaan lima standar pokok yang seharusnya. untuk direalisasikan dan dipertahankan. Kelima keunggulan penting ini yang patut untuk dijaga seorang individu dan untuk itu disampaikan syariat yang berisi perintah, larangan dan persetujuan yang harus ditaati melalui setiap mukallaf.

b. Keinginan untuk al-hajiyah dalam konteks kesadaran dan perlindungan yang diinginkan dalam mempertahankan 5 poin tersebut di atas, tetapi tingkat keinginannya berada di bawah aldaruriyah.

c. Kebutuhan al-tahsiniyyah dengan al-akmaliyah ditujukan agar menciptakan dan menyelenggarakan hal-hal yang membantu peningkatan kualitas 5 kebutuhan dasar masyarakat di atas dan 
mengeluarkan sesuatu yang berkaitan dengan tingkah laku yang mulia. $^{16}$

\section{Dari Segi Keberadaannya}

a. Al-maslahah al-mu'tabarah khususnya maslahah yang secara eksplisit diidentifikasi melalui syara 'dan ditunjukkan dengan dalil-dalil yang unik. Banyak ulama sepakat mengenai tipe ini adalah hujjah syar'iyah yang sah dan benar. ${ }^{17}$

b. Al-maslahah-mulghah, khususnya maslahah yang sekarang tidak didiagnosis dengan syara 'bahkan ditolak dan dipandang palsu dengan menggunakan syara'

c. Al-maslahah al-mursalah adalah maslahah yang tidak lagi secara eksplisit diidentifikasikan oleh hokum islam dan tidak ditolak maupun dianggap palsu melalui hokum islam, secara substansial masih sejalan dengan aturan hokum syara yang lazim. ${ }^{18}$

\section{Dari Segi Kemanfaatanya}

a. Al-maslahah 'ammah adalah keuntungan yang sudah dikenal yang mengkhawatirkan kepentingan banyak manusia.

b. Al-maslahah khassah yaitu keuntungan yang melibatkan kepentingan individu maupun komunitas kecil. ${ }^{19}$

\section{Landasan Hukum Maslahah}

Banyak para ulama mengartikan Landasan Hukum Maslahah yaitu syari'at Islamiyah mencakup manfaat bagi manusia dalam mengatur kehidupan dan kehidupannya di dunia ini, hal ini ditegakkan dalam Alquran

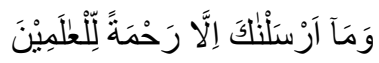

Artinya: "dan Kami sekarang tidak mengirimmu, namun untuk (menjadi) rahmat bagi alam semesta "(Al-anbiya: 107).

Dalam Ungkapan yang jujur beberapa strategi yang dikembangkan oleh sarjana fiqh dalam mengistinbathkan syariat Islam dari teks fikih adalah metode maslahah. Maslahah dipakai dalam

\footnotetext{
${ }^{16}$ Ibid.,

${ }^{17}$ Romli SA, Studi Perbandingan Ushul Fiqh, 224.

${ }^{18}$ Asmawi, Perbandingan Ushul, 129-130.

${ }^{19}$ Nasrun Haroen, Ushul Fiqh 1 (Jakarta: Logos Wacana Ilmu, 1997), 116.
} 

minum...

beristinbath sebagai alat bukti terutama didasarkan pada pandangan adanya illat dalam suatu undang-undang. Mayoritas ulama menegaskan bahwa maslahah bias dipakai sebagai alat bukti atau dalil dalam penyelenggaraan hukum.

Keputusan Menteri Perindustrian dan Perdagangan RI dalam Implementasi Praktek No. 651 / Mpp / Kep / 10/2004 pada Depot Pengisian Air Minum higienis di Kecamatan Balong, Kabupaten Ponorogo

1. Penjelasan Peraturan Keputusan Menteri Perdagangan dan Perindustrian No. 651 / MPP / KEP / 10/2004

Untuk memberikan jaminan produk air minum higienis kelas satu yang diproduksi lewat Depot air minum higienis untuk memenuhi kebutuhan air minum dan membantu terciptanya persaingan bisnis niaga yang jujur dan dalam usaha memberikan keselamatan bagi konsumen perlu adanya hal-hal yang mengatur tentang eksistensi depot air minum isi ulang tetap dengan bantuan para pengusaha dalam menjalankan usahanya sesuai dengan apa yang telah ditentuan bahwa Telah dibuat dan didukung dengan pengawasan lewat instansi yang berwenang, dengan harapan dapat memberikan manfaat kepada lingkungan untuk membantu kebutuhan sehari-hari mereka akan air bersih yang siap dikonsumsi.

2. Isi Keputusan menteri perindustrian dan perdagangan RI No. 651 / MPP / KEP / 10/2004

a. Syarat pemakaian wadah Galon dalam KEPMENPERINDAG RI No. 651 / MPP / KEP / 10/2004 diantaranya yaitu bahwa yang dibawa oleh konsumen harus dibersihkan serta diperiksa sebelum diisi, dan sesudah diisi, wadah gallon ditutup dengan tutup yang tidak bersegel. ${ }^{20}$

${ }^{20}$ Bagian 5 Keputusan Menteri Perindustrian dan Perdagangan Republik Indonesia Nomor 651/ MPP/ KEP/ 10/2004 Tentang Persyartan Teknis Depot Air Minum Isi Ulang dan Perdagangan. 

minum...

b. Depot Air Minum higienis juga boleh hanya menggunakan gallon biasa yang tidak bermerek atau wadah yang sudah tidak dimiliki lagi oleh perusahaan pemilik galon bermerek. ${ }^{21}$

c. Tendon Air Baku Tempat penampungan air higienis yang masih baku harus terbuat dari bahan food grade (bahan tara pangan), bebas dari zat yang dapat mencemari air. Depot air minum sebaiknya tidak menyimpan air minum yang disiapkan untuk ditawarkan dalam bentuk kemasan gallon air minum dalam wadah yang siap dijual. Penyimpanan hanya boleh laksanakan untuk air mentah di tangki penyimpanan (tangka tendon).

3. Praktek Tempat Pengisian Air Minum Isi Ulang di wilayah Balong, Kabupaten Ponorogo

a. Tempat Pengisian Air Minum Delta

Di tempat pengisian air ini, ada galon berbagai produsen yang sudah tidak memperlihatkan keasliannya lagi. Di antara depot isi ulang yang pakai adalah merek Aqua. Adapun penjelasan atau alasan pelaku usaha air isi ulang yaitu dilihat dari antusiasme pasar sebagian besar konsumennya memiliki galon produsen Vit dan Aqua. Jadi pengelola mengikuti menuruti kemauan konsumennya, terkecuali melihat pemilik depot di sekitar. Dia selain menggunakan galon bermerek begitu dia juga ikut bergabung, dia mempertanyakan banyak juga yang menggunakan merek tersebut. Saat kemaren nongkrong, ternyata ada galon bermerek dan apalagi banyak persediaan air dalam gallon. Alasan Pemilik melakukan penimbunan dulu agar jauh lebih mudah untuk mempromosikannya dan mendistribusikanya lagi ke toko grosir, kemudian agar tidak terlalu bermasalah untuk mengganti galon, karena ternyata pelanggan yang sering datang ke depo tidak lagi terpengaruh baik laki-laki maupun perempuan ketika harus menunggu pengisian, maka

${ }^{21}$ Pasal 7 ayat (3) Keputusan Menteri Perindustrian dan Perdagangan Republik Indonesia Nomor 651/MPP/KEP/10/2004 Tentang Persyartan Teknis Depot Air Minum Isi Ulang dan Perdagangan. 
pengelola depot ini mengambil inisiatif mengisi dulu. Adapun kebijakan terkait wadah galon, dia sudah tidak paham lagi.

b. Depo Air Minum Nabawi

Di Tempat Pengisian air isi ulang ini Pak Deny memakai galon dari pabrikan seperti Vit, Siclus dan Fujiro. Ia pun bergabung dengan pemilik depot untuk memanfaatkan perusahaan Aqua guna mendapatkan penghasilan yang cukup. Menurutnya, jika hanya gallon polos, banyak orang akan kurang berminat dan akan membatasi pendapatannya. Jual beli air isi ulang di tempat ini sama seperti di depot air minum delta yang memakai dua model jual beli. Pertama, konsumen datang ke depot dengan galon membawa kosong dan menukarnya dengan wadah galon isi ulang. Kedua, ada delivery order.

c. Depot Air Minum Mahadewi

Berdasarkan informasi dari Pak Bambang, depot tersebut menggunakan gallon bermerk. Galon merk yang digunakan terdiri dari merk Aqua, Siclus, Fujiro. Depo air minum isi ulang Mahadewi melakukan proses pengisian ke dalam wadah atau galon dengan cara menstok air terlebih dahulu agar setiap pelanggan datang untuk meminta isi ulang air kemasan telah siap.

d. Depo Air Minum Isi Ulang Sumber Rejeki

Dari keterangan pelaku usaha air isi ulang, tempat yang pakai untuk mengisi air minum bukanlah galon biasa. dengan kata lain, Segala sesuatu yang dijual untuk diisi memiliki perusahaan sendiri. Dalam prakteknya, pengisian tidak melulu ketika klien datang langsung ke depot untuk meminta air isi ulang. Namun, mereka juga mengisi air ke dalam wadah dengan kata lain tidak di depan pelanggan.

Analisis Maslahah tentang Penerapan KEPMENPERINDAG Ri NO. 651 / MPP / KEP / 10/2004. Mengenai Persyaratan Teknis Depot Air Minum Isi Ulang di Kecamatan Balong, Kabupaten Ponorogo 

minum...

Berdasarkan hasil penelitian, pelaksanaan bisnis didepot air minum isi ulang yang ada di daerah Balong Kabupaten Ponorogo dalam praktek menggunakan galon bermerek dalam melakukan kegiatan usaha niaga. Ketika ditanya mengapa menggunakan merkmerk tersebut, dan jawaban mereka karena tidak mengetahui kebijakan KEPMENPERINDAG 651 / MPP / KEP / 10/2004. Ada yang sudah mengetahui tentang tentang aturan tersebut tapi tetap mengedepankan penggunaan gallon bermerek Aqua, motifnya banyak kliennya yang punya galon dengan merk pabrikan tersebut. Agar pengusaha depot air memenuhi keinginan klien yang memiliki kebutuhan sendiri dalam memilih merek. Tempat air yang digunakan untuk mengisi wadah penampungan air tidak sesuai dengan ketentuan KEPMENPERINDAG 651 / MPP / KEP / 10/2004 Ini sepenuhnya didasarkan pada premis bahwa pelaku pengusaha sekarang tidak memiliki hak untuk memakai dalam wadah atau gallon bermerk tersebut.

Karena itu, penggunaan wadah galon bermerek melalui kemampuan depot menimbulkan persaingan tidak sehat. Sebagaimana diketahui hingga saat ini, maslahah terkandung dalam maqasid al-syari'ah yang telah dikedepankan dengan sumber daya yang bermanfaat dari banyak ulama, terlebih dalam hal menjaga agama, jiwa, akal, keturunan dan harta benda. Dilihat dari strategi maqasid al -syariah dalam hal ini masalah di atas menyimpang dari hifz al-mal, khususnya menjaga harta benda. Hifzul-mal tidak hanya dimaksudkan sebagai jaminan untuk menjaga kepemilikan harta benda, tetapi juga dimaksudkan sebagai larangan mengambil hak atas kekayaan orang-orang, seperti pencurian, korupsi, monopoli, oligopoli, monopsoni dan lain-lain.

Dalam menjalankan usahanya pemilik tempat air isi ulang menggunakan galon bermerek untuk mengisi airnya. Di mana mereka sebenarnya tidak lagi memiliki hak dan izin untuk mengisi air mentah ke dalam wadah galon bermerek, karena hal tersebut sama dengan mengambil atau memakai hak milik orang lain selain izin yang mana properti tersebut merupakan hak kekayaan intelektual. Islam mengajarkan untuk melindungi harta benda, artinya bisnis yang diperdagangkan harus mematuhi syari'at Islam. Padahal sebagian pengusaha paham tentang aturan penggunaan 

minum...

galon tersebut. Hanya saja mereka melewatinya karena telah menjadi ketergantungan seperti yang dilakukan depot air isi ulang lain secara umum.

Berlandaskan data-data subjek yang didapat peneliti, kebanyakan tempat air isi ulang tidak menampung di tempat penampungan yang semestinya melainkan di galon kemasan. Mereka tidak menunggu pelanggan datang tanpa menunda-nunda ke depot untuk meminta galon diisi ulang. Sehingga tempat penampungan atau simpanan selesai tidak lagi di depan pembeli langsung. Praktek ini tidak diperbolehkan sesuai dengan undang-undang Keputusan Menteri perindustrian dan perdagangan RI No.651 / KEP / MPP / 10/2004. Menurut catatan yang peneliti cari, sekarang tidak diperbolehkan menyimpan air ke dalam wadah gallon. karena, Jika mengonsumsi air dari depot tidak langsung maka dalam waktu lebih dari tiga hingga 4 hari, air dalam galon tersebut cenderung terserang penyakit akibat bakteri, jamur dan lumut. Jika dianalisis dengan bantuan derajat maslahah dalam maqasid al-shari'ah dalam frase halus dan penting, khususnya maslahah al-daruriyah hifz al-nafs wa al'irdl untuk memelihara jiwa. Islam membutuhkan keberhasilan kebutuhan biologis. Untuk mempertahankannya, Islam mensyaratkan untuk makan dan mengonsumsi minuman sesuatu yang dapat menyehatkan dan dapat memberikan ketahanan jiwa. Berdasarkan hasil analisa dengan teori maslahah mursalah bahwa pengisian air mentah kedalam galon dalam jumlah besar dengan memanfaatkan para pengusaha tentang pengisian depot air minum di Kecamatan Balong tidak sesuai dengan maslahah al-daruriyah hifz alnafs untuk menumbuhkembangkan jiwa, karena untuk mengakui maslahah yang berkaitan dengan jiwa, wajib makan dan minum sesuatu yang dapat menjadikan sehat dan dapat memberikan ketahanan bagi jiwa.

\section{KESIMPULAN}

Pemakaian galon berlabel dalam jual beli air isi ulang di Kecamatan Balong Kabupaten Ponorogo sudah tidak cocok lagi dengan syarat dan ketentuan yang diatur dalam KEPMENPERINDAG RI Nomor. 651/ KEP/ MPP/ 10/ 2004. Perihal ini diakibatkan sebab melanggar hak kepunyaan orang lain dengan 

minum...

metode pemakaian galon berlabel dari industri lain tanpa izin. Dilihat dari pendekatan maslahah al- daruriyah, dalam hal ini praktek bisnis di atas menyimpang dari hifzul- mal, yaitu mencari kekayaan dengan metode mengambil hak dari kekayaan orang lain tanpa ijin.

Pengisian air baku menjadi air galon dalam membeli serta memperdagangkan air minum isi ulang di Kabupaten Balong saat ini tidak lagi memenuhi syarat Peraturan RIPMENPERINDAG RI Nomor. 651/ KEP/ MPP/ 10/ 2004. Baik isian yang menampung air mentah jadi air galon. serta metode yang saat ini dilakukan oleh pengelola air isi ulang yang tidak memakai baju khusus ketika mengisi air isi ulang. Ditelaah dengan pemikiran maslahah ini, hal tersebut sudah tidak cocok lagi dengan maslahah al- daruriyah hifz al- nafs dalam rangka memelihara jiwa, sebab kebenaran menghasilkan maslahah terpaut dengan jiwa, Islam mensyaratkan untuk makan serta minum dan sebagian perihal yang dapat berguna dan bisa membagikan perlawanan terhadap jiwa. Masyarakat sebagai pelanggan tidak lagi terpenuhi haknya buat makan serta minum supaya senantiasa hidup sehat.

\section{DAFTAR PUSTAKA}

Anharullah, Muhammad. Beralkohol Tapi Halal Menjawab Keraguan

Tentang Alkohol Dalam Makanan, Minuman dan Kosmetik. Solo: Pustaka Aarafah , 2011.

Arfan, Abbas. Geneologi Pluralitas Madzab dalam Hukum Islam.Malang: UIN Malang Pers, 2008.

Asmawi, Studi Hukum Islam. Yogyakarta: Sukses Offset, 2012.

Departemen Agama RI. Al-Quran Al-Kariim. Semarang: Karya Toha Putra, 2002.

Fatwa MUI Nomor: 1/MUNAS VII/MUI/5/2005 Tentang Perlindungan Hak Kekayaan Intelektual (HKI).

Fasa, Muhammad Iqbal. "Reformasi Pemahaman Teori Maqa>șid Syariah Analisis Pendekatan Sistem Jasser Auda," Jurnal Studia Islamika. Yogyakarta: Vol. 13, No. 2 (2016), 232. 
Hasibuan, Hamka Husein. Jasser Auda, Bapak Maqasid Syariah Kotemporer dalam https://islami.co/jasser-auda-bapakmaqasid-syariah-kontemporer/. 29 Maret 2020.

Haroen, Nasrun. Ushul Figh 1. Jakarta: Logos Wacana Ilmu, 1997. Keputusan Menteri Perindustrian dan Perdagangan Republik Indonesia Nomor 651/MPP/KEP/10/2004 Tentang Persyartan Teknis Depot Air Minum Isi Ulang dan Perdagangan.

Koto, Alaiddin. Ilmu Figh dan Ushul Figh. Jakkarta: Raja Grafindo Persada, 2009.

Kusairi, Ahmad. Evolusi Ushul Fiqh. Yogyakrta: Pustaka Ilmu Group, Yogyakarta, 2013.

Mardani. Figh Ekonomi Syariah. Jakarta: Kencana Prenadamedia Group, 2012.

Mubarok, M. Adib.“Praktik Jual Beli Sumber Air Dalam Prespektif Hukum Islam (Studi Kasus Di Desa Ngaditirto Kecamatan Selopampang Kabupaten Temanggung)" ,Skripsi. Yogyakarta: UIN Yogyakarta, 2010.

Muri, Yusuf. Metode Penelitian; Kuantitatif, Kualitatif dan Penelitian Gabungan. Jakarta: Kencana, 2017.

Pujiono. Hukum Islam dan Dinamika Perkembangan Masyarakat. Yogyakarta: Mitra Pustaka, 2012.

SA, Romli. Muqaranah Mazahib Fil Usul. Jakarta: Gaya Media Pratama, 1999. 2004.

Studi Perbandingan Ushul Figh. Yogyakarta: Pustaka Pelajar,

Safira, Martha Eri. Hukum Ekonomi di Indonesia. Ponorogo: CV Nata Karya, 2016.

Tanjung, Hendri dan Devi Abrista. Metode Penelitian Ekonomi Islam. Jakarta: Gramata Publishing, 2013. 